\title{
合成ゴムにおける最近の進歩
}

Advances in synthetic Rubber

\section{ニ, 三の新しい合成ゴムについて}

Several new synthetic rubbers

\section{I. 緒}

\section{論}

最近に抽ける合成ゴム研究の進步はいちじるしく，わ が国においてもその一種である SBR（スチレン・ブタジ エンコポリマー）などの工業化が進められている。これ ら従来の合成ゴムは天然ゴムとは異なった分子構造のも のであったが，最近にいたり立体特異性重合により天然 ゴムと同じ構造の cis $-1,4$ ポリイソプレンの合成に成功 している。またそそれぞれすぐれた特性を持ったポリブ タジエンやフッ素ゴム，安価な $\alpha$ オレフィンの重合に よる良好なゴム，ジイリシアネートを架橋珮とするポリ ウレタンゴムなどが研究され，一部工業化されている。 これら多種頪のゴムを ASTM ではつぎのように分類 している ${ }^{1,2)}$

A：加硫可能のもの

1. ジェンのゴム

2. ジェン以外のゴム

B : 加硫不能のもの括よびその他

さらそゴムの主鎖の化学的組成によりつぎのようと分 類している。

$\mathrm{M}$ ：ポリメチレン型の飽和鎖をもつゴム

$\mathrm{N}$ ：ポリマー鎖にNをむつゴム

$\mathrm{O}$ ：ポリマー鎖にOをもつゴム

$\mathrm{P}$ ：ポリマー鎖にPをもつゴム

$\mathrm{R}$ ：不飽和の炭素結合をもつゴム

たと觉ば少なくとも一部分はシオレフィンから誘 導された合成ゴム括よび天然ゴム

$\mathrm{T}$ ：ポリマー鎖にSをむつゴム

$\mathrm{U}$ ：ポリマー鎖に C，O，N，をるつゴム

また， Rに属するものはさらにつぎのようと分類され る。

* 東京工業大学資源化学研究所（目黒区大岡山）
神 原 周*. 住 江 太 郎* Shū KAMBARA

B R：ブタジエンゴム

I R：イソプレンゴム（合成）

C R：クロロプレンゴム

NR：イソプレンゴム（天然）

A B R：アクリレートーブタジエンゴム

I I R：イソブチレンーイリプレンゴム

N B R ：ニトリルーブタジェンゴム

NCR：ニトリぬータロロプレンゴム

P B R ：ピリジンーブタジエンゴム

SBR：スチレンーブタジエンゴム

S C R：スチレンークロロプレンゴム

SI R：スチレンーイソプレンゴム

限られた紙面と和いて合成ゴムと括ける最近の進歩の すべてとついて述べることはできないのでそこのから 未来の合成ゴムとして興味あるいくつかの話題をひろっ て，解説をこころみる。なお，紙数の都合から単量体の 合成および SBR などの合成ゴムの製造研究などについ てはここではふれない。

\section{II. ポリイソプレン}

天然ゴムはイソプレンが $c i s-1,4$ 結合とより重合して できたポリイソプレンと同し構造をもち，古くからイリ プレンの重合はこころみられたが cis-1, 4 結合のみのホ? リマーは得ることができなかった。1956 年に Fireston? Tire \& Rubber Co. より Coral Rubber,,$^{3,4)}$ Goodrich Research Center より Ameripol SN ${ }^{5)}$ が発表され, 立体特異性重合触媒を用いて cis-1, 4 ポリイソプレンの 合成が可能となり，これらは合成によってつくられた天 然ゴムという意味で合成天然ゴム (Synthetic Natural

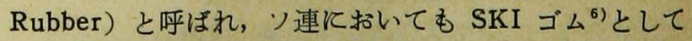
研究が進められている。このほか A. V. Tobolsky らも Li-dispersion ゃ $n$-Butyl Li を触媒として炭化水素 
溶媒中でイソプレンを重合させ，90９6\% cis-1，4 ポ リイソプレン（粘度平均分子量 $2,000 〜 15,000$ )を得て 括り ${ }^{10 \sim 12)}$ ，わが国に括いても当研究室でチグラ一型触媒 を用いた cis $-1,4$ ポリイソプレンの合成に成功》て，京 大の古川研究室に预いてもカドミウム触媒を用いて cis

$$
\begin{aligned}
& \text { イソプレン } \stackrel{\stackrel{\mathrm{CH}}{\mathrm{C}}}{\mathrm{CH}_{3}=\mathrm{C}-\mathrm{CH}=\mathrm{CH}_{3}}
\end{aligned}
$$

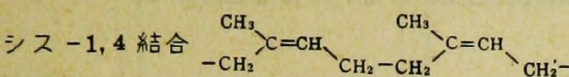

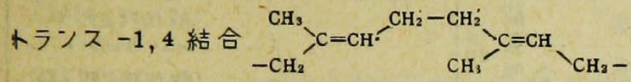

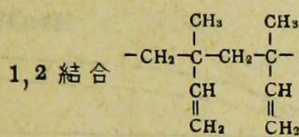

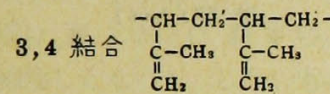

図 1 ポリイソプレンの立体構造

$-1,4$ ポリイソプレンの合成に成功している ${ }^{8,9)}$ 。

合成天然ゴムの合成に成功したというととは単に学問 的に重要なばかりでなく，実用の面に扔いてもきわめて 重大な意義を持っている。すなわち従来の合成ゴムは耐 熱性や耐油性などの特殊な面に括いては天然ゴムよりす ぐれた性質をもっているものもあるが，一般に絽返しの 伸縮により内部発熱を扢としやすく，そのためゴムの最 あ大きな用途であるタイヤに使用することができず， SBR であ乗用車タイヤには使えるがバス，トラック， 航空機などの荷重の大きいもののタイヤには使用でき ずもっぱら天然ゴムのみが用いられていたが，天然ゴ ムと同じ構造を持つ合成天然ゴムが経済的にひきあう程 度に安価飞得られるならば，この方面へ利用される可能 性は十分あり，天然ゴムとそっくり持きかえるととので きる合成ゴムとして将来の発展が期待されている。

1. Coral Rubber ${ }^{3,4)}$ このゴムはFirestone Tire \& Rubber Co. そ抢いて研究されたもので，石油または ワセリン中にとまかく分散させた $\mathrm{Li}$ 金属を触媒に用い ており，その粒子径は約 20 ミクロンといわれている。
仕込みの割合はイソプレン 100 部につき $\mathrm{Li} 0.1$ 部で, $30 \sim 40^{\circ} \mathrm{C}$ で重合させて天然ゴムとほぼ同じ程度の分子 量をもつポリマーを得ており，ロールで練った時の分子 量の変化（表 1）もその分子量分布（表 2）も天然ゴム

表 1 Coral と天然ゴムの素練りとよる分子量の变化

\begin{tabular}{|c|c|c|c|}
\hline ゴムの種類 & 素練りの程度 & 極限粘度 & $\begin{array}{c}\text { 分子量 } \\
\text { (数平) }\end{array}$ \\
\hline Coral Rubber & 0 & 7.0 & 669,000 \\
& 20 回 & 2.2 & 230,000 \\
天 然 ゴム & Break down & 1.7 & 178,000 \\
& 0 & 7.4 & 680,000 \\
& Break down & 1.6 & 141,000 \\
\hline
\end{tabular}

ときわめてよく似た結果が得られている。

その赤外吸収スペクトルを天然ゴムと比較すると図 2 のごとく両者は良く一致しており，ほとんど同じ化学構 造を持っていることがわかる。

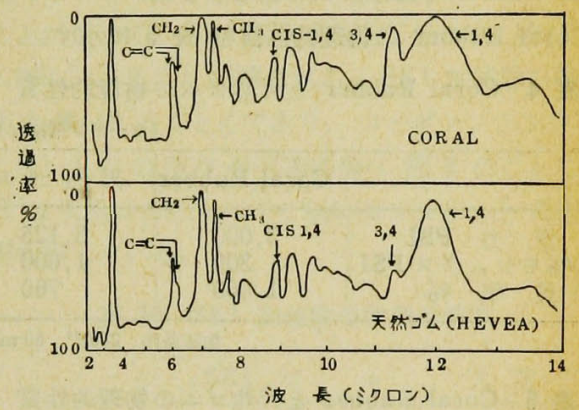

図 2 Coral Rubber と天然ゴムの赤外吸収スペクトル

表 3 は各種 Coral Rubber の化学構造の分析值であ るが trans-1，4 結合および 1, 2 結合は全くなく，天 然ゴムにくらへててわずかに 3,4 結合が多いが 天然ゴム とほとんど同じ構造というととができる。

また，伸長された状態の Coral Rubber と大然ゴムの X線回折図はたがいによく似た特性をもち，引きのばさ れた状態の Caral Rubber の結晶成分は天然ゴムと同じ cis-1, 4結合が Head to Tail 型飞規則正しくつらなって いることを示している。引きのばした天然ゴムは最高40 $\%$ 近くの結晶化を括こすが，1,000\%に伸長した Coral Rubber では約 $25 \%$ の結晶化が打こるといわれている。

加硫物の物理的性質は 表 4 のごとくであり，抗張力 は天然ゴムにくらべて Coral Rubber のほうがごくわ

表 2 Coral と天然ゴムの分子量分布（極限粘度-ポリマー\%）

\begin{tabular}{|c|c|c|c|c|c|c|c|c|c|c|c|c|c|}
\hline 極 限 粘 度 & $0 \sim 2$ & $2 \sim 4$ & $4 \sim 6$ & $6 \sim 8$ & $8 \sim 10$ & $10 \sim 12$ & $12 \sim 14$ & $14 \sim 16$ & $16 \sim 18$ & $18 \sim 20$ & 20 以上 & $\mid \begin{array}{l}\text { ゲル } \\
\text { 部分 }\end{array}$ & $\begin{array}{l}\text { アセトン } \\
\text { 抽出分 }\end{array}$ \\
\hline 天 然 ゴ ム & 3.7 & 6.0 & 7.4 & 7.2 & 11.7 & 27.0 & 7.2 & - & - & - & - & 26.2 & 3.6 \\
\hline Coral RS- 88 & 3.0 & 7.0 & 9.4 & 11.2 & 9.9 & 6.1 & 23.0 & - & - & - & - & 27.4 & 3.0 \\
\hline Coral PP-1352 & 0.7 & 1.7 & 2.7 & 4.4 & 6.3 & 8.2 & 43.0 & 9.8 & 2.6 & 1.6 & 5.6 & 8.4 & 5.0 \\
\hline
\end{tabular}


表 3 Coral Rubber の化学構造（二重結合の分布\%)

\begin{tabular}{|l|c|c|c|c|}
\hline & cis-1,4 & trans-1,4 & 1,2 & 3,4 \\
\hline Hevea & 97.8 & 0 & 0 & 2.2 \\
Balata & 0 & 98.7 & 0 & 1.3 \\
RS-104-A & 93.8 & 0 & 0 & 6.1 \\
RS-105-12 & 93.4 & 0 & 0 & 6.5 \\
RS-110-6 & 92.8 & 0 & 0 & 6.5 \\
RS-118-F & 93.4 & 0 & 0 & 6.0 \\
1552 & 93.6 & 0 & 0 & 6.4 \\
1557-R & 94.1 & 0 & 0 & 5.9 \\
CPP-1029 & 91.3 & 0 & 0 & 8.6 \\
CPP-1188 & 91.5 & 0 & 0 & 8.4 \\
CPP-1428-R & 92.9 & 0 & 0 & 7.5 \\
RS-85-1 & 92.5 & 0 & 0 & 7.4 \\
RS-99-B & 93.7 & 0 & 0 & 6.3 \\
CPP-1469 & 93.0 & 0 & 0 & 6.9 \\
\hline
\end{tabular}

ずか低いがほとんど等しいとみるととができ，また，モ ジラスは Coral Rubber のほうが低いが伸長率は Coral Rubber のほうが大である。また，カーボン補強 の Coral Rubber の物理的性質を 表 5 飞示す。

表 4 Coral Rubber と天然ゴムの物理的性質

\begin{tabular}{|c|c|c|}
\hline & 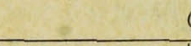 & カーポン補強なし \\
\hline & Coral Rubber & 天然ゴム \\
\hline 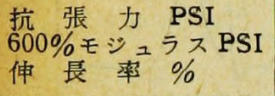 & $\begin{array}{r}3,000 \\
300 \\
1,060\end{array}$ & $\begin{array}{r}3,125 \\
1,000 \\
760\end{array}$ \\
\hline
\end{tabular}

加硫条件 $280 \mathrm{~F}^{\circ} 60 \mathrm{~min}$

表 5 Coral Rubber と天然ゴムの物理的性質 (EPC カーボンフフック $35 \mathrm{PHR}^{*}$ 補盂)

\begin{tabular}{|c|c|c|}
\hline & Coal Rubber & 天然コム \\
\hline 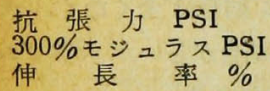 & $\begin{array}{r}3,775 \\
400 \\
800\end{array}$ & $\begin{array}{r}4,275 \\
1,000 \\
630\end{array}$ \\
\hline
\end{tabular}

加硫策件 $280^{\circ} \mathrm{F} \quad 60 \mathrm{~min}$ •PHRはコム100 部当り

HAF カーボンブラック 50 PHR 補強の Coral Rubber の内部摩擦を天然ゴムと低温重合 SBR にくらべると図

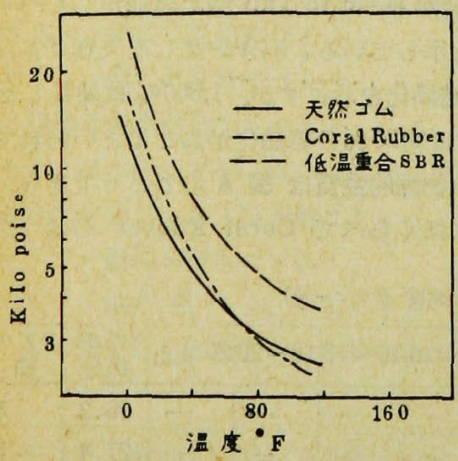

図 3 温度と内部摩擦との関係

(HAFカーボンフラック 50PHR 補强)
3 のごとくで，比較的高い温度では SBR よりはるが 低く天然ゴムとほほ等しいかあるいはそれ以下であり， したがって伸縮による発熱は少なく実際のタイヤによる 走行試験を行った結果をみてす, Coral Rubber と天然 ゴムのタイヤの内部発熱はほほ等しいが亀裂に対する抵 抗は Coral Rubber のほうが大きい。これは図 4 に 示すごとく，天然ゴムよりあ Coral Rubber のほうが 酸素吸収速度がおそいためと思われる。

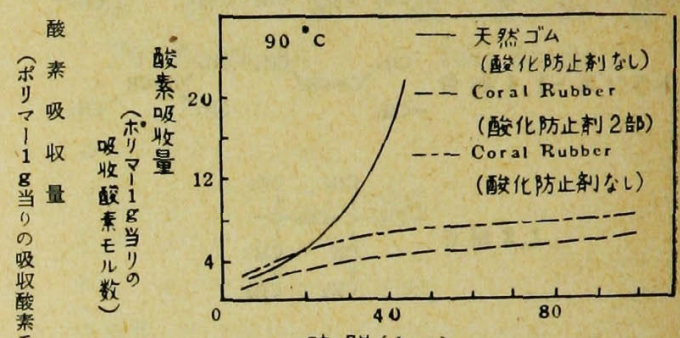

晴間 $(\mathrm{hrs})$

図 4 酸素吸収速度

2. Ameripol SN S) $^{5)}$ このゴムは B. F. Goodrich Research Center そ括いて研究されたもので, 改良した チグラー型触媒を用いてイソプレンを重合させたすのと いわれるが重合条件などの詳細はまだ発表されていな い。ポリマーの分子量は 表 6 のごとくで天然ゴムの数 平均分子量 838,000 そくらへて 230,000 と大分低いが, 数 平均分于量と粘度平均分子量との比は天然ゴで 2.54, Ameripol SN で 2.86 と良く似た分子量分布を持って いることがわかる。

表 6 Ameripol SN と天然ゴムの分子量

\begin{tabular}{|c|c|c|c|c|c|c|}
\hline & $\left|\begin{array}{c}\text { 分分 } \\
\%\end{array}\right|$ & $\begin{array}{c}\text { Swelling } \\
\text { Index }\end{array}$ & 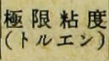 & 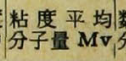 & 数子平均 & $\frac{\mathrm{Mv}}{\mathrm{M}_{\mathrm{n}}}$ \\
\hline Ameripol SN & 6.3 & 126 & 3.80 & 658,600 & 230,000 & 2.86 \\
\hline $\begin{array}{l}\text { Ameripol SN } \\
\text { (低 分子 量) }\end{array}$ & 0 & - & 1. 32 & 135,000 & 77,200 & 1.75 \\
\hline 天 然 ゴ & 11.6 & 127 & 8. 30 & $2,126,000$ & 838,000 & 2.54 \\
\hline \begin{tabular}{lll} 
天然 & \multicolumn{1}{c}{} \\
(素 練 & 後)
\end{tabular} & 0 & - & 1. 47 & 157,700 & 118,700 & 1.33 \\
\hline
\end{tabular}

天然ゴムと Ameripol SN の赤外吸収スペクトルを 比較すると図 5 のごとく，2〜25 ってきわめてよく一致しているととがわかる。また， Ameripol SN $-26^{\circ} \mathrm{C}$ で涷結させた時およびその加 硫物を $1,000 \%$ 亿引き伸ばした時のX線回折図は，それ に対応する天然ゴムのX線回折図とよく似た特性を示 し、このことからも Ameripol SN の化学構造が天然コ ムのそれとほとんど同じすのであることがかかる。 

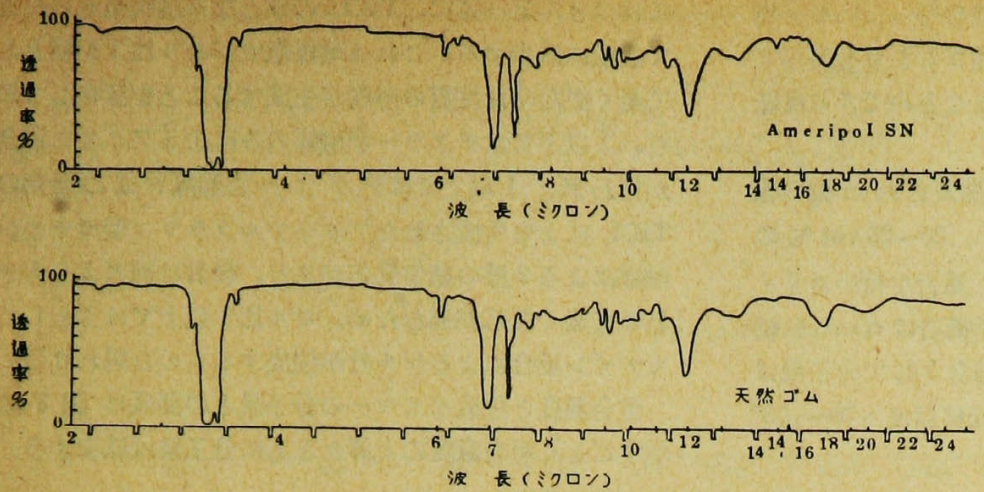

図 5 Ameripd SN 天然ゴムの赤外吸収スペクトル
して十分天然ゴムにとってかわ ることができ, 従来の合成ゴム にはみられなかった汎用ゴム (General use rubber) として 多くの方面に利用することがで きる。

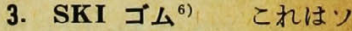
連で研究されている合成ポリイ ソプレンのゴムで，重合触媒や 重合条件などは発表されていな いので不明であるが 3,4 結合 を6〜7\%含むほかはすへて cis $-1,4$ 結合により構成されてい
Ameripol SN は加工性が良く，他の合成ゴムと同様 飞素練りを行う必要はないが，天然ゴムと同様の加硫を 行うためにはタンパク質を加え，イオウや脂肪酸を少し 多く配合しなければならない。Ameripol SN の加硫物 の物理的性質は表 7 および 表 B のごとくで，カ一ボ ンブラック補強したものも，しないものも天然ゴムとほ とんど同じ性質をもっている。

表 1 Ameripol SN 加硫物（カーボン補強なし） の物理的性質

\begin{tabular}{|c|c|c|}
\hline & Ameripol $\mathrm{SN}^{*}$ & 天然ゴム \\
\hline 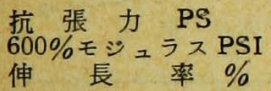 & $\begin{array}{r}3,550 \\
700 \\
850\end{array}$ & $\begin{array}{r}3,410 \\
790 \\
830\end{array}$ \\
\hline
\end{tabular}

加硫条件 $280^{\circ} \mathrm{F} \quad 30 \mathrm{~min}$

・1.5PHR の添加物（レンチン $95 \%$, トリエタノールアミン $5 \%$ ）を 添加

表 8 Ameripol SN 加硫物（カーボン補強）の 物理的性質

\begin{tabular}{|c|c|c|}
\hline & Ameripol $\mathrm{SN}$ & 天然ゴム \\
\hline 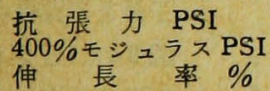 & $\begin{array}{r}3,900 \\
2,250 \\
600\end{array}$ & $\begin{array}{r}4,080 \\
2,570 \\
570\end{array}$ \\
\hline
\end{tabular}

加硫条件 $280^{\circ} \mathrm{F} 45 \mathrm{~min}$ タイヤトレッド用処方

42 PHR ISAF カーボンブラック補强

表 9 はタイヤ走行試験の結果で，亀裂に対する抵抗 も保（も）ちも幾分天然ゴムに劣るが，この程度の性質 を持っていれば重目荷用タイヤ(Heavy duty tire) と

表 9 Ameripol SN のタイヤ走行試験

\begin{tabular}{|c|c|c|c|}
\hline & \begin{tabular}{|l} 
告じた售㤠の \\
表さ総計 in
\end{tabular} & 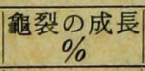 & 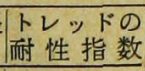 \\
\hline $\begin{array}{l}\text { Ameripol SN No. } 1 \\
\text { Ameripol SN No. } 2\end{array}$ & $\begin{array}{l}64 \\
98\end{array}$ & $\begin{array}{l}245 \\
265\end{array}$ & 85 \\
\hline $\begin{array}{llll}\text { 天 然 } コ \text { 品 } & \text { No. } 3 \\
\text { 天 然 } & \text { ム } & \text { No. } 4\end{array}$ & $\begin{array}{l}20^{1} / 2 \\
22 \frac{1}{2}\end{array}$ & $\begin{array}{l}248 \\
191\end{array}$ & 100 \\
\hline
\end{tabular}

るといわれ，そのX線回折図をみても天然ゴムと良く似 た構造であることがわかる。SKI と素練り後の天然ゴ ムとがたがいに良く似た弾性と可塑性を持っているとい うことからみて，SKI の数平均分子量は 約 100,000 200,000 であろうと推察される。SKI 加硫物の物理的 性質は 表 10 のごとくであり，カーボンブラック袢強 をしないものの歪力-伸長率曲線は 図 6 のごとくで， SKI は天然ゴムにくらべて低いモジュラスと大きな体 長率を持っている。

\section{表 10 SKI 加硫物の物理的性質}

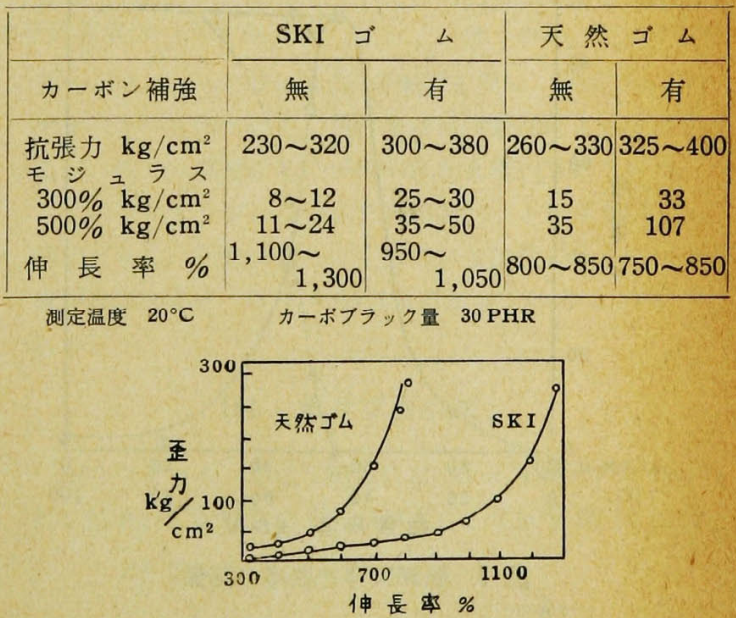

図 6 SKI と天然ゴムのストレスー伸長率 (カーボン補強なし)

繰返しの屈曲による内部発熱は, カーボンブラック補 強なしのものでは SKI と天然ゴムはほほ同じで，補強 したものでは天然ゴムよりも SKI のほうがいらじるし く少ない。また，熱による老化に対しては，カーボンブ ラック補強なしのものでは SKI む天然ゴムもほとんど 等しい抵抗性を示すが，補強したものでは天然ゴムにく 
らぺて SKI のほうがすぐれた抵抗性を持っている。物 理的性質は一般飞 SKI のほうが天然ゴムよりも少って いるが，十分天然ゴムにとってかわることのできる良好 な性質を持っている。

SKI の研究が行われた研究所から発表された他の報 告 $^{13)}$ そよれば，チグラー型触媒を用い，20２5 vol％の ベンゼン溶液中 $40 \sim 60^{\circ} \mathrm{C}$ で $5 \sim 6 \mathrm{hr}$ 重合を行いポリイ ソプレンを得ている。ポリマーの化学構造は cis-1, 4 結 合 93 94\%，3，4 絬合 3\%，1,2 結合 3\% で分于量は $250,000 \sim 300,000$ であり, その二次転移点は $-70 \sim-73^{\circ}$ C であるといわれている。

\section{4. チグラー型触媒を用いたイソプレンの重合 ${ }^{7}$}

(東京工業大学 神原研究室の研究)

1957 年より当研究室に括いても，イソプレンの合成 およびその重合の研究を行い, cis-1,4 ポリイソプレン の合成に成功した。

触媒にはトリエチルアルミニウム $\mathrm{Al}\left(\mathrm{C}_{2} \mathrm{H}_{5}\right)_{3}$ (以下 $\mathrm{AlEt}_{3}$ と略記）と四塩化チタン $\mathrm{TiCl}_{4}$ より調製したチ グラー型触媒を使用した。触媒として用いる $\mathrm{AlEt}_{3}$ と $\mathrm{TiCl}_{4}$ のモル比と生成ポリイソプレンの化学構造との間 にはきわめて深い関僁があることが実験により明らかに なった。すなわち 図 7 に示すごとく $\mathrm{TiCl}_{4}$ と $\mathrm{AlEt}_{3}$

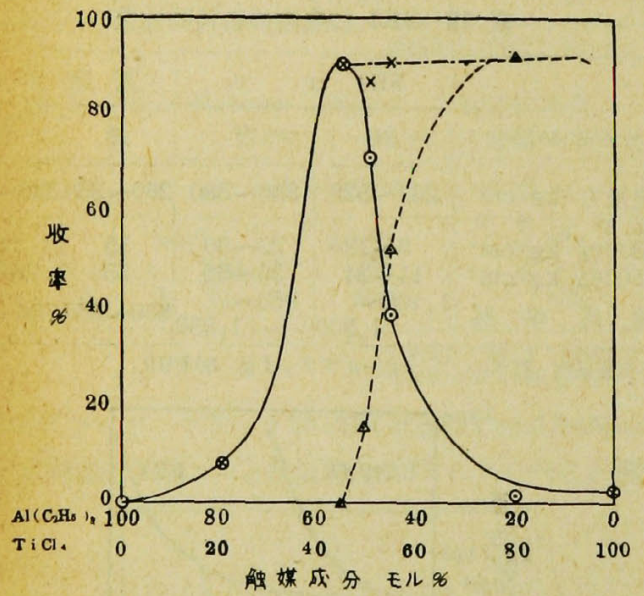

図 7 触媒成分と収率の関係

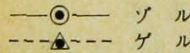
-.-

イソプレン $1 \mathrm{~mol}$ $\mathrm{Al}\left(\mathrm{C}_{2} \mathrm{H}_{5}\right)_{3} 0.1 \mathrm{~mol}$ $\mathrm{O}^{\circ} \mathrm{C}, 5 \mathrm{hr}$

とのモル比とポリマーのゲル分（主としてtrans $-1,4$ 結 合ポリマー）およびゾル分（主として cis-1, 4 結合ポリ マー) の収率との関係をみると, $\mathrm{TiCl}_{4} / \mathrm{AlEt}_{3}$ モル比が 0.8 の点でゔル分の収率は極大となる。また，モル比 1 以上ではゾル分の収率は急激に減少し，かわりにゲル分 の収率が増加するためポリマー全収率はモル比 0.8 以上
ではほとんど一定で， $\mathrm{TiCl}_{4}$ のみとなる触媒組成の付近 で急激に減少する。これは触媒組成がモル比 1 を境とし て全く異なった性質の触媒が生成することを意味してょ り，1以下ではチグラー型触媒のみによるアニオン重合 が行われ，1以上ではチグラ一型触媒玄よび過剩の $\mathrm{TiCl}_{4}$ Kより生成されたフリーデルクラブッ型カチオン 触媒による 2 種の競争反応があり，後者は前者よりもき わめて速く反応が進むため，モル比 1 以上では主として カチオン重合によるゲル分が生成するものと思われる。

重合温度と生成ポリマーの分子量との関係は 図 8 K 示すごとく重合温度の上昇とともに分子量は娍少する。

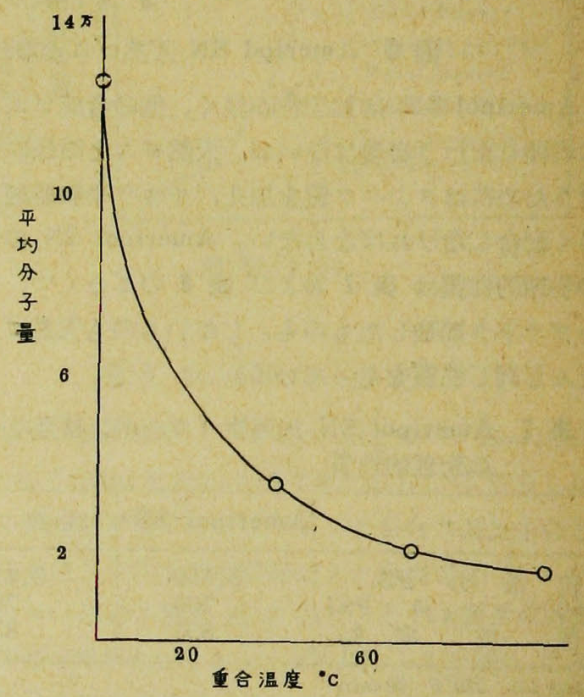

図 8 重合温度と平均分子量の関係 $\begin{array}{ll}\text { 1ソフレン } & 1 \mathrm{~mol} \\ \mathrm{Al}\left(\mathrm{C}_{2} \mathrm{H}_{5}\right)_{3} & 0.1 \mathrm{~mol} \\ \mathrm{TiCl}_{4} & 0.04 \mathrm{~mol}\end{array}$

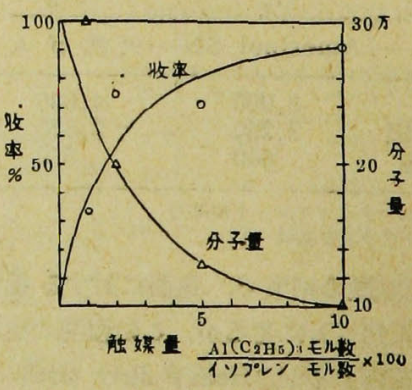

図
触媒量の分子量および収 率 (ペンゼン可溶部) と拈よ ほす影響

重合条件

$\mathrm{Al}\left(\mathrm{C}_{2} \mathrm{H}_{5}\right)_{3} / \mathrm{TiCl}_{4}=1 / 0.8$
反応温度 $0^{\circ} \mathrm{C}$

反応時間 $5 \mathrm{hr}$
また，触媒量 と収率括よび分 子量との関係は 図9のごとくて 触媒量の增加に したがって収率 は増加するが分 子量は逆に減少 する。

ポリイソプレ ンの化学構造を しらべるため, $\mathrm{TiCl}_{4} / \mathrm{AlEt}_{3} 0.8$, $0^{\circ} \mathrm{C}$ で重合させ
たポリマースついて赤外吸収スペタトルを測定し，これ を天然ゴムと比較した（図 10）。これより明らかなごと 


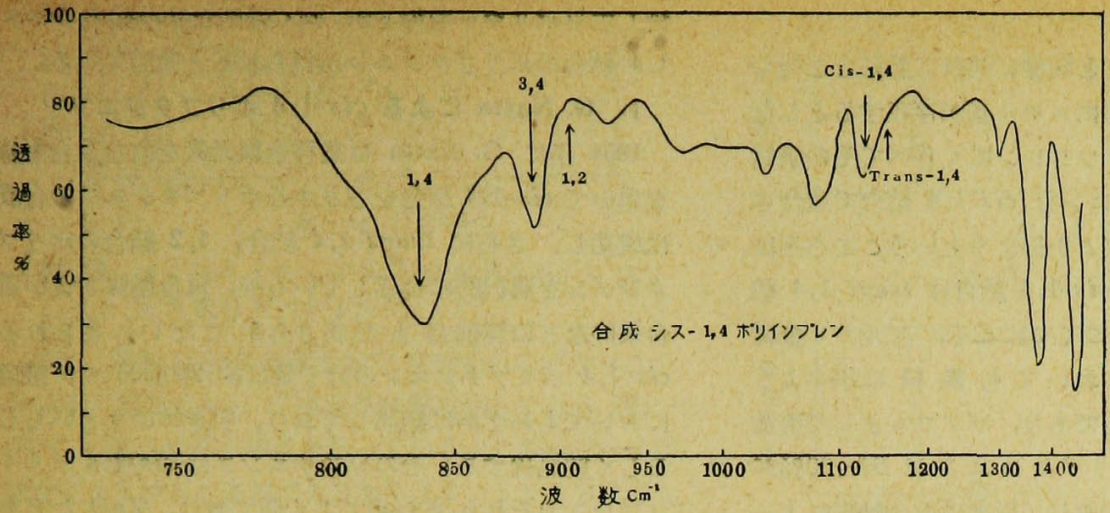

1,4 結合により構成 されていると推定さ れる。

また，合成ポリイ ソプレンを天然ゴム と同じ処方の配合で 加硫するときわめて 優秀な性質を持つ加 硫物が得られる。

5. 有機カドミウ 么化合物を触媒とす るイソプレンの重 合 8,99

（京都大学 古川研 究室の研究）

この研究は京都大 学古川研究室に括い てなされたもので， ジエチルカドウム $\mathrm{Cd}\left(\mathrm{C}_{2} \mathrm{H}_{5}\right)_{2}$ と $\mathrm{TiCl}_{4}$ の混合触媒を用いて イソプレンの重合を 行っている。反応温 度 $40^{\circ} \mathrm{C}$, 反応時間

図 10 合成シス $-1,4$ ポリイソプレンと天然ゴムの赤外吸収スペクトル

く，合成ポリイソプレンにはtrans 1,4 結合および 1,2 結合の吸収は全く表われておらず，わずかに 3,4 結合 を含むのみで大部分は cis-1;4 結合より構成されてい る。スペクトルよりみると， 3,4 結合の量は天然コムよ りわずかに多いが, $890 \mathrm{~cm}^{-1}$ に扑り 3,4 結合の吸光 係数はきわめて大きく，3,4 結合の含有量 $2 \%$ 天然ゴ ムです図 10 程度の吸収を示すことからみても，合成ポ リインプレンの 3,4 結合は $5 \%$ 以下で $95 \%$ 以上は cis-

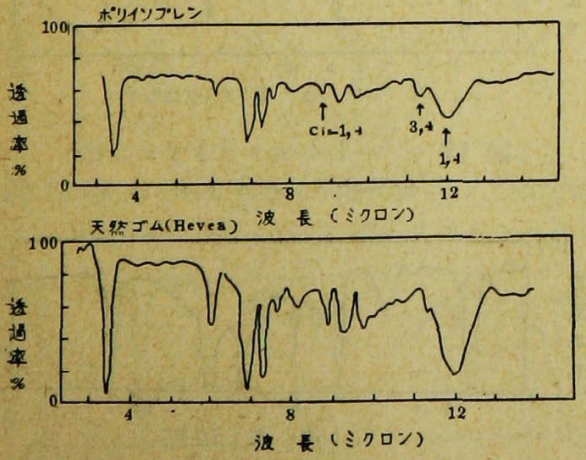

図 11 ポリイソプレンと天然ゴムの 赤外吸収スペクトル
$12 \mathrm{hr}$ ，モノマーの $3 \mathrm{~mol} \%$ の触媒を用い，50\%の収率 でポリマーを得ている。重合度は重合条件により変化す るが, 約 600 程度のものが得られたと報告されている。

このポリインプレンの赤外吸収スペクトルは図 11 に 示すごとく，天然ゴムとよく似ており少量の 3,4 結合の ほかはほとんど cis-1,4 結合よりなっていると推定さ れる。

\section{III. ポリブタジエン}

ポリブタジエンの化学構造には cis $-1,4$ 結合, trans1,4 結合， 1,2 結合の 3 種類があり，これを図 12 に示

ブタジエン $\mathrm{CH}_{2}=\mathrm{CH}-\mathrm{CH}=\mathrm{CH}_{2}$

シスー1,4 結合 $-\mathrm{CH}^{\prime}{ }^{-\mathrm{CH}=\mathrm{CH} \backslash} \mathrm{CH}_{2}-\mathrm{CH}_{2}^{-}-\mathrm{CH}=\mathrm{CH} \backslash \mathrm{CH}_{2}-$

トランスー1,4結合 $-\mathrm{CH}_{3}^{-}-\mathrm{CH}=\mathrm{CH}^{-\mathrm{CH}_{2}-\mathrm{CH}_{2}^{\prime}} \mathrm{CH}^{\prime} \mathrm{CH}_{\mathrm{CH}_{2}-}^{\prime}$

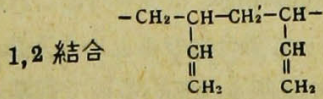

図 12 ポリブタジエンの立体構造 
す。

ブタジエンはイソプレンと同様に共役二重結合を持つ 化合物で分子構造上は側鎖にメチル基が存在するとしな いとのちがいしかなく，イノプレンにくらへてその価格 む低いととから，ブタジエンを cis-1,4 結合で重合さ せて天然ゴム類似の良質ゴムを得ようというこころみは 古くから行われていたが, cis -1,4 結合は trans $-1,4$ 結 合や 1,2 結合にくらべてつくりにくく，アルカリ金属 触媒を用いて行った重合に和いても表 11 亿示すよう そcis-1,4 結合は最高 35\%であり，ブナゴムとして製造 された $\mathrm{Na}$ 触媒によろポリブタジエンは 60 ～80\%が 1,2 結合により構成されて括り, 従来の重合触媒によっ ては cis-1, 4 結合を主体々するポリブタジエンを得る ことはできなかった。

表 11 アルカリ金属螌媒により重合させたポリ ブタジエンの化学構造 ${ }^{\text {) }}$ (表中の数字はま\%)

\begin{tabular}{|c|c|c|c|}
\hline 触 媒 & cis $-1,4$ 結合 & trans $-1,4$ 結合 & 1,2 結合 \\
\hline $\mathrm{Li}$ & 35 & 52 & 13 \\
\hline $\mathrm{Na}$ & 10 & 25 & 65 \\
\hline $\mathrm{K}$ & 15 & 40 & 45 \\
\hline $\mathrm{Rb}$ & 7 & 31 & 62 \\
\hline Cs & 6 & 35 & 59 \\
\hline アルフィン & 11 & 71 & 18 \\
\hline 乳化重合 & 18 & 64 & 18 \\
\hline
\end{tabular}

しかしながら最近の発表によれば，イタリアの G. Natta は 1954 年に cis-1,4 ポリブタジエンの合成 ${ }^{14)}$ 飞成功し, Phillips Petro. Co. 屯 1956 年飞 cis-1, 4 ポリブタジエンの合成に 成功したと発表 ${ }^{15}$ し， 1957 年

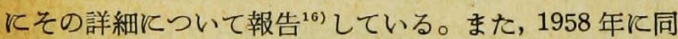
社より発表された $80 \%$ cis $-1,4$ ポリブタジエンは低温 そ扔いてきわめて優秀な性質をもつととが発表され また, R.S. Aries は 130 th Am. Chem. Soc. Meeting (1956) ${ }^{19)}$ て Butyl-Li とチタン塩化物を触媒として, $80^{\circ} \mathrm{C}$ オクタン中でブタジエンの重合を行い，数平均分 子量 220,000 の cis-1,4 ポリブタジエンを得たと報告 し，その加硫物の性質は抗張力 5,240 PSI, 伸長率 $820 \%$ で内部発熱も少なく，酸素や浴㓮に対する抵抗性も天然 ゴムより大きいといわれ，cis-1,4 ポリブタジエンは将 来性のあるゴムとして注目されている。

また,ブタジエンの特殊な重合法として, 最近 canel complex を用いた立体特異性重合が報ぜられている これは尿素の結晶格子の長い孔の中にブタジンモノマ 一が入った canel complex をつくり, これに $1 \mathrm{~m}$. e. V.の電子線を照射して重合させるという方法で，モノ、 一は結晶格子そより規制されているので側鎖のできない 立体規則性の重合が進み，重合終了後，水洗して尿素を 流し去りポリマーを得るが，硬く強靯な結晶性のtrans 1,4 結合のポリブタジンンが得られると報じている。

1. G. Natta による cis-1,4 ポリブタジエン ${ }^{14)}$

1954 年飞 G. Natta は遷移金属元素を含む重合触媒 を用いて cis-1,4 結合を主とするポリブタジエンの合成 飞成功し，さら飞 trans-1,4 結合， 1,2 結合のポリブ タジエンを選択的に合成しているが，重合触媒および重 合条件などの詳細はまだあきらかでない。得られる cis-1, 4 ポリブタジエンの分子量は約 200,000 で，室温 とおいてもわずかと結晶して抢り，引き伸ばすといちじ るしく結晶化する。そのレシリエンスは cis $-1,4$ ポリイ ソプレンのそれときわめてよく似ており，ZnO などを 用いた普通の処方で加硫するととができる。

表 12 は cic 抽よび trans-1, 4 結合と 1,2 結合の 非結晶状ポリブタジンの弾性を示すものであるが, cis-1,4 結合のものは常温，高温飞かかわらずすぐれた 弾性をもっている。trans-1-4 結合もかなり良い弾性を 持っているか， 1,2 結合は常温と招いて 1,4 結合より もかなり劣った弾性を持つとすぎない。

表 12 ポリブタジンン加硫物の Rebound (\%) (ASTM D1054-49Tによる视定)

\begin{tabular}{|l|c|c|}
\hline \multicolumn{1}{|c|}{ 測 定 温 度 } & $20^{\circ} \mathrm{C}$ & $90^{\circ} \mathrm{C}$ \\
\hline trans $-1,4$ 結合 & $75 \sim 80$ & $90 \sim 93$ \\
cis $-1,4$ 結合 & $88 \sim 90$ & $92 \sim 95$ \\
1,2 結合 & $45 \sim 55$ & $90 \sim 92$ \\
\hline
\end{tabular}

図 13〜15 は各結合様式のポリブタジンの赤外吸収 スペクトルで, trans-1,4 結合では純度 $98 \%$ 以上のも のも得られているが完全飞 cis-1,4 絬合のみのポリブタ シエンは得られていなく，図13よりみて少量のtrans1,4 を含んでいると思われる。

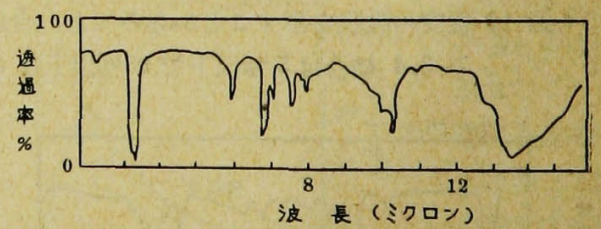

図 13 シス $-1,4$ ポリブタジエンの 赤外吸収スペクトル

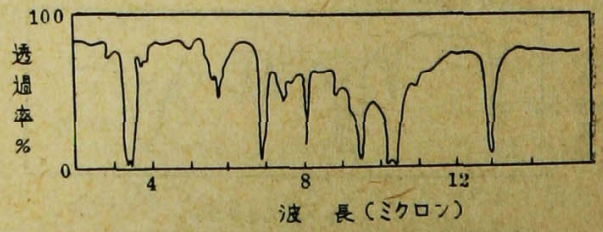

図 14 トランス $-1,4$ ポリブタジンンの 赤外吸収スペクトル 


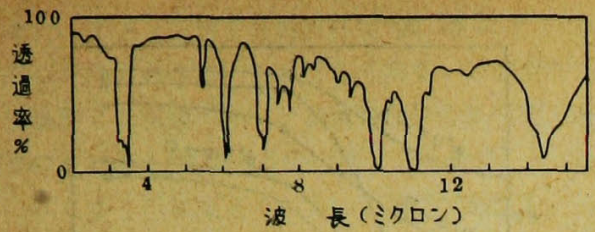

図 15 アイソタクチック $-1,2$ ポリブタジエンの 赤外吸収スペクトル

また，98\%以上の純度をもつ trans-1, 4 ポリブタジ エンは，常温においては高度に結晶化しており 140〜 $180^{\circ} \mathrm{C}$ の相当に高い融点を持っている。この結晶化の程 度を引き下げことができるならばモジュラスの大きな 硬質ゴムを，また，適当沉加硫すれば常温においても良 い弾性をもつゴムをつくることができると思われる。

2. Phillips Petroleum Co. によるポリフタジエ ン ${ }^{16)}-1,4$ ポリブタジエンの cis-trans 比率による性 質の变化 1,4 ポリブタジエンにおいてその組成を cis $95 \%$ か trans $100 \%$ まで変えた場合, cis-trans 比率によるポリマーの性質の変化に関しては, 以下述へ るような興味ある研究が Phillips Petro. Co.によって 行われた。

この研究には異相系の立体特異性重合触媒により炭化 水素溶媒中，一定温度で重合させたポリブタジエンを試 料としており，表 13 に示すような異なった cis-trans 比率のポリマーについていろいろの珄質の比較を行った ものである。

表 13 ポリブタジン（未加硫）の物理的性質

\begin{tabular}{|c|c|c|c|c|c|c|}
\hline \multirow{2}{*}{$\begin{array}{l}\text { ポリマ } \\
\text { 記 }\end{array}$} & \multicolumn{3}{|c|}{ 化 学 構 造 (\%) } & \multirow{2}{*}{ 不飽和 } & \multirow{2}{*}{$\begin{array}{l}\text { 固有 } \\
\text { 粘度 }\end{array}$} & \multirow{2}{*}{ 粘 } \\
\hline & cis $-1,4$ & trans $-1,4$ & 1,2 & & & \\
\hline A & 95.2 & 0.6 & 3.3 & 98.7 & 4.25 & 150 \\
\hline B & 91.2 & 0.9 & 3.4 & 94.1 & 2.67 & 40 \\
\hline C & 87.3 & 4.3 & 4.1 & 94.9 & 2.45 & 34 \\
\hline D & 81.8 & 8.3 & 4.3 & 95.4 & 2.30 & 34 \\
\hline E & 67.0 & 25.9 & 1.5 & 97.0 & 2.40 & 40 \\
\hline F & 36.0 & 50.6 & 10.7 & 94.8 & 2.13 & 35 \\
\hline G & 24.7 & 71.9 & 2.9 & 94.6 & 2.12 & 43 \\
\hline $\mathrm{H}$ & 16.6 & 80.5 & 2.9 & 95 & 1.78 & 29 \\
\hline I & 5.0 & 93.4 & 2.2 & 93.2 & & - \\
\hline
\end{tabular}

図 16-18 はそれぞれポリマーA，E，I の赤外吸収ス ペクトルで, cis-trans 比率の変化飞よるスペクトルの

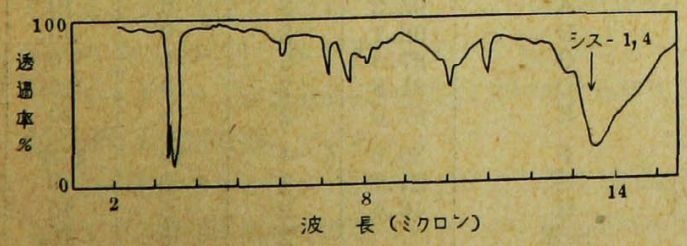

図 16 ポリマーA

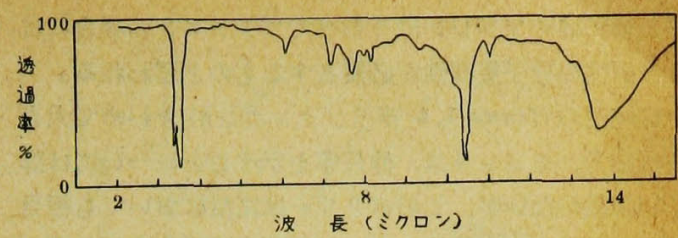

図 17 ポリマーE

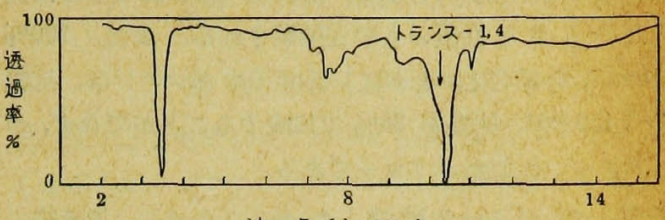

波 長(ミクロン)

図 18 ポリマーI

ちがいがよく表われている。

次にポリマーの性質が cis-trans 比率によってどの ようにかわるかをみるために，各試料につき架橋結合数 が同じであるような加硫物をつくり，その物理的性質を 比較した。

まず 1,4 ポリブタジエン加硫物（カーボン補強なし） について，cis 含有率に対する抗張力， 300\%モジュう ス，伸長率などの関係は 図 19 のごとくで，抗張力，モ ジュラスとも谷型で 36〜82\% cis 含有率の間ではほと んど一定で，両端が急激に上昇している。これは，両端 の cis または trans の含有率の高いところでは分子配 列の規則珄が増すためと思われる。cis 合有率は $95.2 \%$

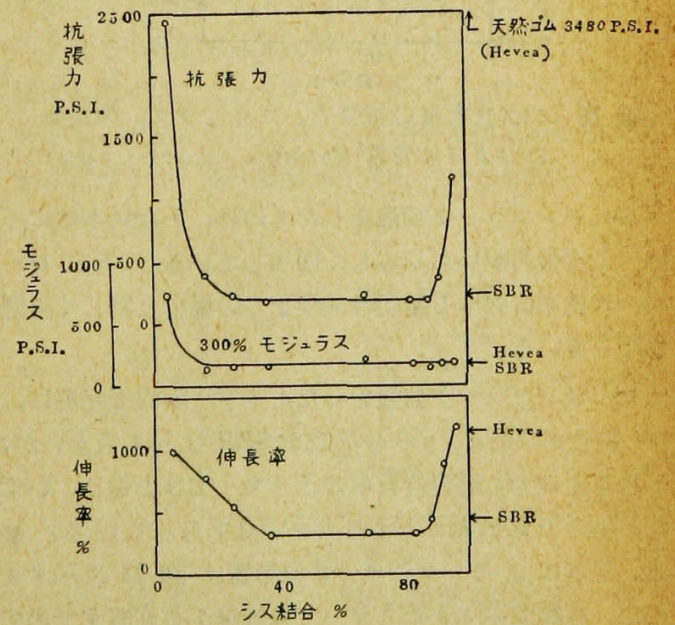

図 19 シス合有量の抗張力，モジュラス， 伸長率に括よぼす影響

が最高であり，これは夭然ゴムの cis 含有率に匹敵する あので，モジュラス，伸長率は天然ゴムとほとんど等し いが抗張力では相当に劣って括り，同程度の抗張力をも 
つためにはイソプレンにくらべてブタジエンの場合には より高度の分子規則性を必要とするものと思われる。

高純度の trans-1,4 ポリブタジエンがきわめて大き い抗張力, モジュラス，伸長率を示すことについては詳 しい説明がないが，このポリマーは常温においても相当 結晶化していて高延伸によって高度の結晶化をおこすた め異常に高い抗張力を示し，伸び切った状態でもとに戾 らないような性質のものと推察される。また，100\% trans-1,4 結合といわれているポリブタジエンは，抗張 力 2,450 PSI, 伸長率 $28 \%$ で加硫するととができず，ポ リエチレンに似たポリマーである。

カーボンブラック補強したポリブタジエン加硫物の cis-trans 比率と抗張力， $300 \%$ モ゙ュラス，伸長率と の関係は図 20 そ示すごとくである。
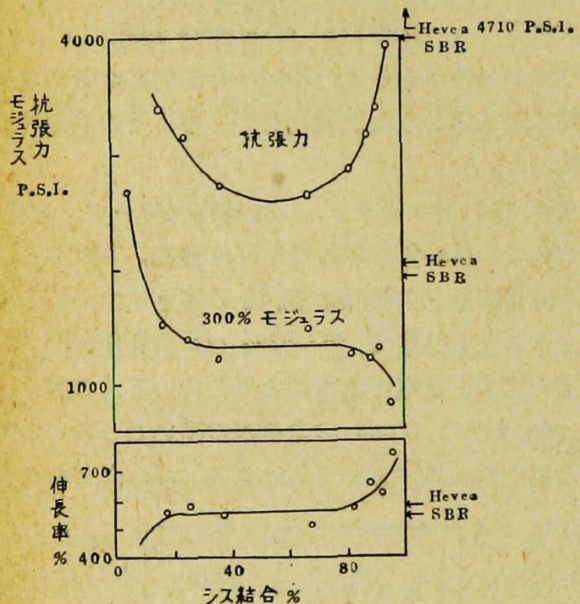

図 20 シス含有量の抗張力，モジュラス，伸長率 そおよほすす影響（50 PHRカーボンフフラック補蚛）

カーボンブラック補強をしたものは，しないものにく らべて抗張力がいちじるしく増加しているが, その cistrans 比率に対する傾向は補強なしの場合と同じく谷型 をなしている。

カーボンブラック補強をしたポリマーの内部発熱は, cis 結合が 70\%以下のものでは SBR よりも大きいが， それ以上の cis 結合含有率のポリマーでは小さく，いず れの場合でも天然ゴムより大きい值をもっている。ま た，温度によるレジリエンスの影響は図 21 に示すよ う火，高純度の cis ポリマーでは低温から高温までの広 い範囲にわたってすぐれており，特に低温においては天 然ゴムよりかなり優秀な性質を持っている。100\% cis1,4 ポリブタジエンはまだ合成されていないが，これは 顕著な物理的性質をむっていると予想され，このポリマ 一の合成に大きな期待がかけられている。

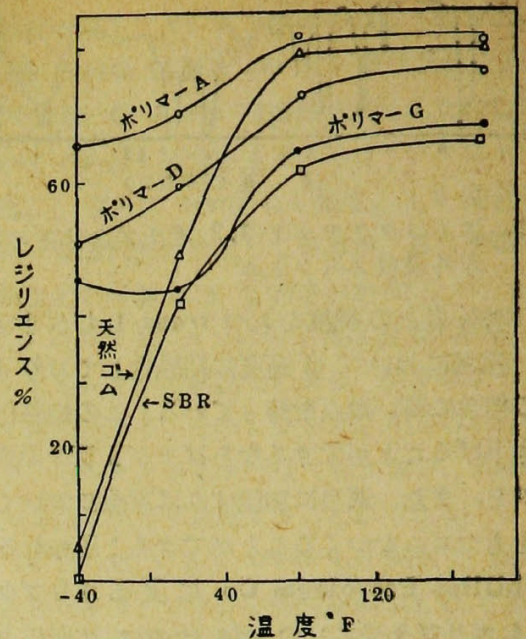

図 21 レジリエンスと温度との関係

分子鎖の酸化切断による胥力の弛緩は 表 14 のごとく で，酸化に対する抵抗性は大で天然ゴムや SBR よりを はるかにすぐれている。測定方法は一定の歪をかけたま ま $100^{\circ} \mathrm{C}$ 飞放置し，一定時間後の歪力 $f_{i}$ を測定し，初 期の歪力 $f_{0}$ との比を求めたものである。

表 14 ポリブタジエン加硫物（カーボンブラック 補強）の酸化による歪力の変化

\begin{tabular}{|c|c|c|c|}
\hline $\begin{array}{l}\text { ポリマー } \\
\text { 記 号 }\end{array}$ & cis- $\%$ & $f_{2} / f_{0}$ & $f_{48} / f_{0}$ \\
\hline $\begin{array}{l}\text { A } \\
\text { B } \\
\text { C } \\
\text { D } \\
\mathbf{E}\end{array}$ & $\begin{array}{l}95.2 \\
91.2 \\
87.3 \\
81.8 \\
67.0\end{array}$ & $\begin{array}{l}0.83 \\
0.81 \\
0.81 \\
0.84 \\
0.76\end{array}$ & $\begin{array}{l}0.80 \\
0.79 \\
0.77 \\
0.75 \\
0.76\end{array}$ \\
\hline $\begin{array}{c}\mathrm{F} \\
\mathrm{G} \\
\mathrm{H} \\
\mathrm{SBR} \\
\text { 天然 コム }\end{array}$ & $\begin{array}{l}36.0 \\
24.7 \\
16.6 \\
- \\
-\end{array}$ & $\begin{array}{l}0.80 \\
0.78 \\
0.66 \\
0.79 \\
0.72\end{array}$ & $\begin{array}{c}0.81 \\
0.76 \\
0.75 \\
0.58 \\
0=f_{20} / f_{0}\end{array}$ \\
\hline
\end{tabular}

測定条件 $100^{\circ} \mathrm{C}$ 酸素中

$f_{2}, f_{d 8}$ はそれぞれ $2,48 \mathrm{hr}$ 後の歪力を表わす

表 15 ポリブタジエン加硫物（カーボンブラッタ 補強）の耐オゾン性

\begin{tabular}{|c|c|c|c|c|}
\hline ポリマー記号 & cis- $\%$ & 2 日後 & 7 日後 & 14日後 \\
\hline A & 95.2 & 2 & 9 & 10 \\
B & 92.1 & 3 & 9 & 10 \\
C & 87.3 & 5 & 9 & 10 \\
D & 81.8 & 2 & 8 & 10 \\
E & 67.0 & 2 & 9 & 10 \\
F & 36.0 & 4 & 10 & 破壊 \\
G & 24.7 & 1 & 6 & 9 \\
H & 16.6 & 2 & 5 & 10 \\
SBR & - & 2 & 5 & 10 \\
天 然 ゴム & - & 1 & 3 & 5 \\
\hline
\end{tabular}


またオゲンに対する抵抗性は表 15 と示すごとく， 天然ゴムにくらへてていらしるしく少る。この表の值は， 25\%延伸した状態でオゾンを含む空気中に放置した時, 表面に表われる亀裂の多少を示したものて，0：亀裂な し，10：多くの奐裂あり，という基準で測定を行ったも のである。

3. $80 \%$ cis-ポリブタジエン ${ }^{17) ~}$ 約 $80 \%$ の cis $-1,4$ 結合を含むポリブタジエンは低温汸いてもすぐれた 物理的性質を持つととを前項で述へたが，ここでは Phillips Petro. Co. に扔いて研究された cis-1,4 結合 $78.6 \%$, trans $-1,4$ 結合 $16.6 \%, 1,2$ 結合 $4.8 \%$ よりな り，ムーニ一粘度 $18\left(\mathrm{ML}-4,212^{\circ} \mathrm{F}\right)$ のポリブタジエ ンと天然ゴム括よび SBR との低温と括ける性質の比較 を紹介する。条件を同しにするため，架橋結合の密度が 同してあるような各ゴムの加硫物（50 PHR カーボンブ ラック補強) を試料として種々の比較を行っている。

Gehman 凍結点測定器による 倲結点の測定の絬果は

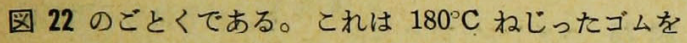
測定温度に放置し，一定時間後にねじりの力を除去した 時のゴムの戾り触を広い温度範囲にわたって測定した あので，低温と抢いて直線状に下っている線を真直にの ばし，横軸との交点をもって凍結点とするもので，これ によると SBR は $-52^{\circ} \mathrm{C}$, 天然ゴムは $-61^{\circ} \mathrm{C}$, ブタシ エンゴムは $-97^{\circ} \mathrm{C}$ の凍結点を示し SBR よりも $45^{\circ} \mathrm{C}$, 天然ゴムよりも $36^{\circ} \mathrm{C}$ も低い凍結点を持っている。

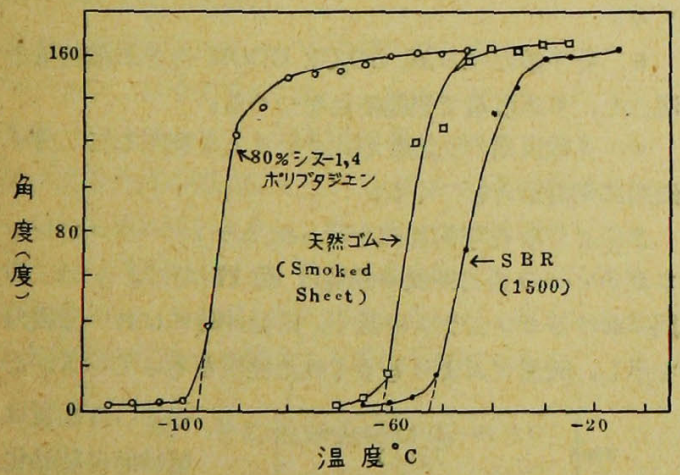

図 22 ネジレの戾る角度と温度との関係

図 23 は戻りの性質と温度との関係で，250\% 亿延伸 したまま测定温度に $22 \mathrm{hr}$ 放置したのち延伸を解き， $20 \mathrm{~min}$ 後にその戾り\%を測定したもので，他のゴムよ りポリブタシェンは低温の広い範囲て扮いてきわめて良 好な戻りの性質を持っている。

また，温度のレジリエンスとおよほすす影響は 図 24 の ごとくで，常温に扔いてはポリブタジンも天然ゴムや SBR と同しような值を示すが，天然ゴムと SBR は温

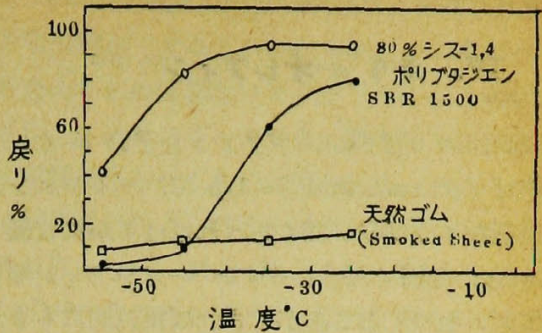

図 23 温度と戾りの関係

度の低下とともにレジリエンスも急速に低下する。しか しながらポリブタジンンイおいては温度が低下してもレ ジリエンスの低下は緩慢で，0〜 -60 $\mathrm{C}$ の範囲では天然 ゴムや SBR にくらべてきわめてすぐれたレジリエンス をむっている。

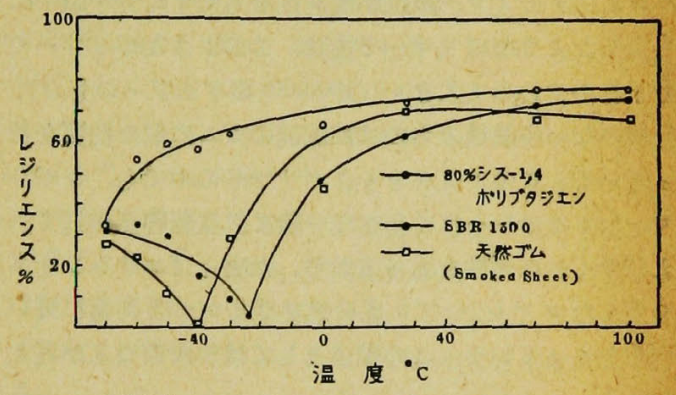

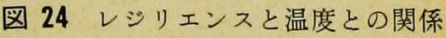

図 25 はショアー硬度と温度との関係を示したもので， 天然ゴムと SBR に执いては $-15^{\circ} \mathrm{C}$ 付近より温度の低 下とともに硬度も急激に増加するが，ポリブタシエンの 硬度の增加はごくわずかで， $-55^{\circ} \mathrm{C}$ においてもSBR の $-20^{\circ} \mathrm{C}$, 天然ゴムの $-35^{\circ} \mathrm{C}$ の硬度とほほ同等の硬度を 示すにすきず，相当低温までやわらかさを保っているこ とができる。

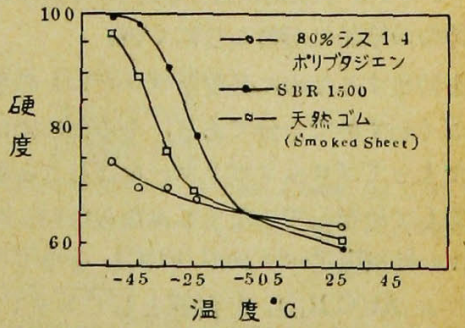

図 25 ショアー硬度と温度との関係

以上述べたごとく $80 \%$ cis-ポリブタジエンは天然ゴ ムや SBR にくらべて低温においてむ結晶化の傾问が少 なく，他のゴムでは使用できないような低い温度と拉い ても軟らかさを保ちかつすぐれた弾性をるっているとと から，この構造のポリブタジエンは特に極寒地用の低温 
そ耐えるゴムとしてきわめて有用なるのである。

\section{IV. ボリ $\alpha$-オレフィン 14,20,21)}

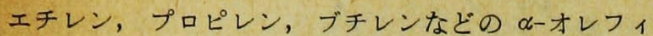
ンの価格はブタジエンの $1 / 3 \sim 1 / 5$ で, ブタジンンより さらに高価なイソプレンにくらべればはるかと安価であ る。これらの安価で入手しやすい 料としてゴムをつくるととができれば経済的にもきわめ て有利なととである。このことはイタリアの G. Natta そより研究され，エチレンとプロピレンからすぐれた性 質のゴムを合成することに成功している。

๙ーオレフィンを立体特異性重合触媒を用いて重合させ ると触媒の種類により結晶性アイソタクチックポリマー や非結晶性アタクチックポリマーが得られるが，後者は $d お よ ひ ゙ l モ ノ マ ー$ 単位が規則性をるたずに分子鎖中に 分布したようなポリマーであり，このようなポリマーで 分子量がきわめて大きく $(100,000$ のオーダーのもの), 分枝のない直鎖状のものは加硫前のゴムに似た性質を持 っている。このアタクチックポリマーの中でも，コポリ マーはホモポリーにくらへて一般に二次転移点が低く， よりすぐれた弾珄をもって扔り，たとえばエチレンを多 く含んだエチレンープロピレンコポリマーは非常に高い 弾性をもっている。この理由としてはつぎのことが考え られる。

a. プロピレンの多く入ったポリマーの分子鎖には $-\mathrm{CH}_{2}-\mathrm{CH}\left(\mathrm{CH}_{3}\right)$-の結合が多く, これにくらべてエチレ ンが多いポリマーでは $-\mathrm{CH}_{2}-\mathrm{CH}_{2}$-の結合が扔もである ので前者にくらへて後者は分子鎖のまわりの自由回転性 が大であるから分子鎖の柔軟性が増す。

b. 非結晶性ポリプロピレンよりもエチレンープロピ レンコポリマーのほうが二次転移点が低い。

c. プロピレンが不規則に分子鎖中に分布しているた め, 非延伸時の結晶化が扔こりとくい。

結晶化を防止するためと必要なプロピレンの量は, 理 論的にはごくわずかで十分であり，そのためにはプロピ レンがかたまってブロックポリマーを作ることなく分子 鎖中反平均して分布していなくてはならない。

G. Natta は三塩化バナジル $\mathrm{VOCl}_{3}$ とトリへキシル アルそニウム $\mathrm{Al}\left(\mathrm{C}_{6} \mathrm{H}_{13}\right)_{3}$ を触媒としてェチレンープロ ピレンの共重合 ${ }^{20,21)}$ を行った結果より，それぞれの reactivity ratio を求め $\mathrm{IO}_{2} \mathrm{H}_{4}=17.95, \mathrm{r}_{3} \mathrm{H}_{6}=0.065$ と いう值を得ている。このようにェチレンの反応速度はプ ロピレンにくらへて桁違いに大きく，との得られた reactivity ratio そより任意の組成のエチレンープロピ レンコポリマーを合成することが可能となった。

プロピレン含有率の異なるエチレンープロピレンコポ リマーについて，含有率と弾性の関係をしらへると図 26 のごとくで, プロピレン含有率が減ると弾性は逆に 増加している。

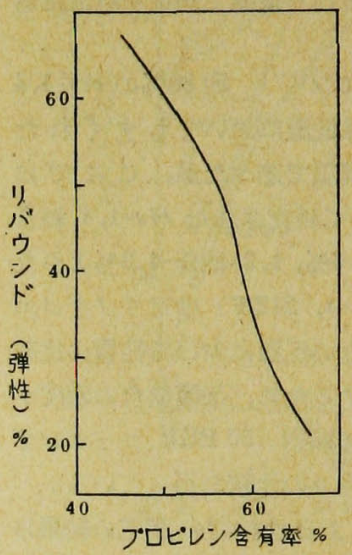

図 26 エチレンープロピレ ンコポリマー中のプ ロピレン量の弾性に およほすす影響

未加硫のアタクチッ クポリマーするよひ非結 晶性コポリマーは長時 間歪力をかけておくと クリープを括こすの で,このままではゴム として使用できないが つぎに述べる加硫を行 ろことによってこの問 題は解決される。ポリ ムーオレフィンの加硫に は化学的加硫と物理的 加硫との二種類があ り，前者は分子鎖間に 化学的方法により架橋 結合をつくるもので，

これにはつぎの 3 つの

方法がある。

a 、シシオフィンまたは反応性に富む官能基をすつモ， オレフィンを共重合により分子鎖中に不規則に導入して 扣き，二重結合または官能基の反応により架橋結合をつ くる。

b. 分子鎖に $\mathrm{SO}_{2} \mathrm{H}, \mathrm{SO}_{2} \mathrm{Cl}, \mathrm{COOH}$ などの酸性基を 導入し, 多価塩基で架橋結合をつくる。

c. 3 級炭素の反応性が大きいととを利用して，分子 鎖間飞架橋結合をつくる。

このような化学的加硫を行ったエチレンープロピレン コポリマーの丕力伸長率曲線は 図 27 のごとくで, 初 期淿けるモジュラスは低く，高延伸時には高い抗張力 を示し，天然ゴムよりもすぐれた性質をむっている。と

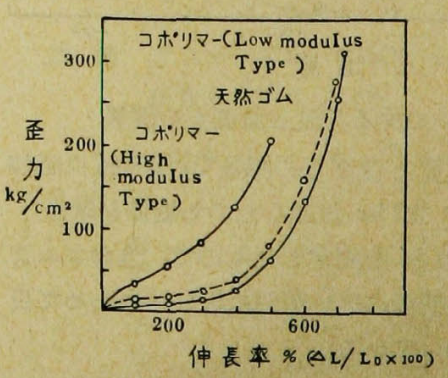

図 27 エチレンープロピレンコポ リマーと天然ゴムの歪力伸長率曲線
のような性質は 延伸時に結晶化 るおとすポリマ 一の特性で, 規 則正しいメチレ ン結合の連続が 部分的に存在す るようなコポリ マーの構造によ るものと思われ る。 
物理的加硫というのは,アタクチックポリマーの分子 鎖の中にアイソタクチックミクロクリスタルの部分がと ころどころにあるようなステレオブロックポリマーをつ くり，これを延伸処理して結晶化による分子鎖間架橋を 行う方法であり，この方法により加硫したステレオブロ ックポリマーの歪力-伸長率曲線は 図 28 のどとくであ り，また，伸長率は分子量の増加とともに増し，結晶性 の増加により逆に減少する。

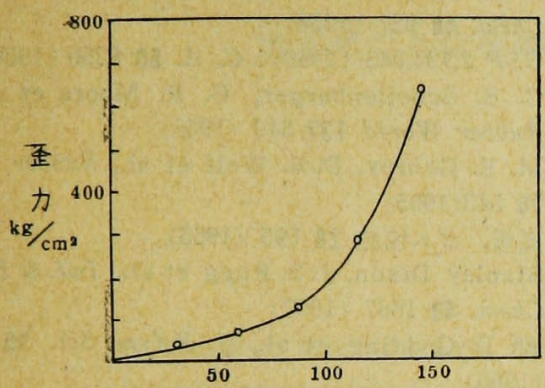

伸長率\%

図 28 延伸処理をしたステレオブロック ポリマーの昰力ー伸長率曲線

化学的加硫を行ったポリマーでは一たん成型したもの を再び成型しな招すととはできないが，物理的加硫を行 ったステレオブロックポリマーには溶融して何度でも成 型しなおすととができるという特徴があり，このような 性質は従来の加硫ゴムにはみられなかったもので，非常 『興味深いものである。

なおささきにアセチレンを全部共役二重結合をもつポ

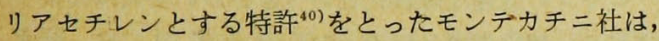
さらにそれをアセチレン系炭化水素と $\propto$ はオレフンの 高分子共重合体の製造にまでひろけた特許 ${ }^{(1)}$ を提出し た。これによればアセチレンとスチレンの共重合もでき るように記載されており，得られるものはトウ黄色固体 とのみ記され，ゴム状となる記述はないが，新しい合成 ゴムの進路を示唆する興味ある重要な発明である。

\section{マ. その他の合成ゴム}

ウレタンゴムはグリコールと 2 塩基塩とから合成した ポリ:スステルをジイソシアネートで連結，架橋したもの で, Vulcollan ${ }^{22-30)}$, Ghemigum SL $\mathrm{SL}^{27 \sim 30)}$, Adiprene $\mathrm{B}^{27,28,31,32)}$ などがすでと工業化されているが，特定の ジイソシアネーネは相当高価であり，また，これによる 架橋反応は空気中の湿気により影響をうけやすく，未反 応で残っているジイシアネートが生ゴム保存中に架橋 して網状構造化を括こし加工性が悪くなるという久点が あったが，最近これらの欠点を改良した Adiprene C ${ }^{39}$
が Du Pont 社から発表された。これは天然ゴムと同様 の配合で加硫ができるといわれており，不飽和ポリエス テルをあらかじめ安価なジイソシアネートで連結して線 状ポリウレタンをつくって括き，鎖中の不飽和結合を利 用して架橋反応を行うものと思われる。また， ウレタン ゴムは架祜反応による網状化操作と同時に成型加工を行 う必要があったが, 最近 B. F. Goodrich 社から発表 された Polyurethane VC V $^{33}$ は架橋反応を行う必要がな く，熱可塑性のエラストマーであるのでその成型加工が きわめて容易でありかつすぐれた物理的性質を持ってい る。一般にウレタンゴムは天然ゴムと同等またはそれ以 上の物理的性質をもつ優秀な弾性体で，他のゴムにはみ られないすぐれた耐摩擦性，耐油性および而溶剤性を特 徴としており，タイヤ，伝動ベルトまたは油や溶剤と接 する部分のパッキングなどの用途に適しているが，アル カリや酸に弱く，また，耐熱性も悪く $140^{\circ} \mathrm{C}$ 以上では いちじるしく劣化するという欠点がある。

また，フッ素ゴムとしては Kel-F エラストマー ${ }^{34,35), ~}$ Viton-A ${ }^{36)}$ ，Poly-FBA ${ }^{35,37)}$ などがあげられるが，これ らはすぐれた熱安定性と耐化学薬品性とを特徵としてお り，高温においても耐油，耐溶剤性が良いので他のゴム では使用に耐えないような部分のパッキング，リング， ホース拈よび被㠅材料などとしてきわめて有用なゴムで ある。

現在使用されているゴムの主鎖はほとんどが炭素原子 の結合により構成されているが炭素以外の窒素, ホウ 素リンなどの無機原子が結合した鎖からなるゴムが特 殊耐熱材料として研究 ${ }^{38)}$ されている。これらは研究途上 であって実用に耐える工業材料として一般に使用される までには至っていないが，現在のゴムでは耐えられない ような高温においても使用できる特殊なゴムとしてその 将来の発展が期待される。

\section{文}

献

1) $\mathrm{ASTM} \mathrm{D} 1418-56 \mathrm{~T}$

D $1419-56 \mathrm{~T}$

D $1420-56 \mathrm{~T}$

2) B. S. Garvey, Ind. \& Eng. Chem. 491593 (1957)

3) F. W. Stavely et al., ibid. 48778 (1956)

4) G. Alliger, J. J. Allen et al., Rubber World 134549 (1956)

5) S. E. Horne, C. F. Gibbs et al., Ind. \& Eng. Chem. 48784 (1956)

6) K. F. Anikanova, A. K. Znamenskaya, Rubber Chem. \& Techn. 3130 (1958)

7) 神原, 山崎, 住江, 工化誌 62299 (1959)

8) 古川, 樹脂加工 7130 (1958)

9) 三枝, 化学 13445 (1958)

10) A. V. Tobolsky et al., J. Polym. Sci. 25245 
(1957)

11) A. V. Tobolsky et al., ibid. 26240 (1957)

12) A. V. Tobolsky et al., J. Am. Chem. Soc. 79 5853 (1957)

13) I. I. Bordirea, B. A. Dorgoprosk et al., Chemical Science \& Industry (SSSR) 3391 (1957)

14) G. Natta, The Rubber \& Plastic Age June 495 (1957)

15) Rubber World 134268 (1956)

16) J. N. Short, G. Kraus, The Rubber \& Plastic Age 38880 (1957) ; Rubber Chem. \& Techn. 30 1118 (1957)

17) H. E. Railsback, Q. L. Morris, Rubber World 13875 (1958)

18) Chem \& Eng. News 36 No. 17, 47 (1958)

19) R. S. Aries, 130 th Am. Chem. Soc. Meeting (1956) Division of Rubber No. 4.

20) G. Natta, G. Mazzanti et al., Chem. \& Ind. (Millan) 39733 (1957)

21) G. Natta, G. Mazzanti et al., ibid. 39743 (1957)

22) O. Bayer, Rubber Chem. \& Techn. 23812 (1950)

23）佐藤, 別冊化学工業 高分子化学工業 (3) 合成ゴ 么篇 p. 124 (1958) 化学工業社

24）村橋, 竜谷, 大有機化学 23 (II) p. 179 (1958)
朝倉書店

25) 佐藤, ラパーダイジェスト 7 No. 12,2 (1955)

26) 佐藤, ibid. 8 No. 2,38 (1956)

27) 芦田, ケミカルニュース 2 No. 8,22 (1957)

28) 芦田，化学技術 2 No. 4, 15 (1958)

29) N. V. Seeger, E. A. Singlair et al., Ind. \& Eng. Chem. 452538 (1953)

30) Le Bras, "Rubber" p. 326 (1957) Chem. Publishing Co.

31) F. B. Hill, R. G. Arnold et al., Ind. \& Eng. Chem. 48927 (1956)

32) USP 2,734,045 (1956); C. A. 508250 (1956)

33) C. S. Schollenberger, G. R. Moore et al., Rubber World 137549 (1958)

34) M. E. Conroy, D. R. Wolf et al., Rubber Age: $76543(1955)$

35）高橋，ゴム協誌 28595 (1955)

36) Stanley Dixon, J. S. Rugg et al., Ind. \& Eng. Chem. 491687 (1957)

37) W. D. Codding et al., J. Polym. Sci. 15515. (1955)

38) W. Postelnek, Rubber World 136543 (1957)

39) W. G. Ogden, ibid. 136537 (1957)

40) モンテカチニ：日特 241491

41) " : 日特公 7193 (昭 33)

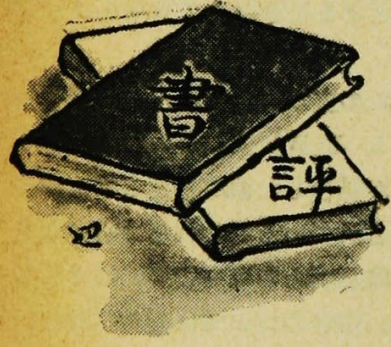

『化学工業の

企業分析』

R. S. Aries

柳沢栄一訳

185 ページ

価 800 円

化学工業日報社

本書は R. S. Aries 博士の原著 “Economics of the Chemical Industry”を“化学工業の企業分析”と表題 を変えて出されたものであるが，内容は技術ならびそ経 済の面からみた化学工業の実体执よび特性とその将来の 予測について論じたものである。Aries 博士は本書の第 5 章 “米国化学工業発展の統計的考察”で次のごとく述 ベている。長期とわたる 化学製品製造工業の成長率は 1929〜1950 年の時期に，その間 1930 年の深刻な不況を 経験したにもかかわらず，年平均 $9 \%$ の生長率で伸びて いる。その時期に全製造工業の生長率の平均が $2.9 \%$ ま た,この間の人口增加率は年 $1 \%$ であった。特に有機合成 化学工業の成長率の増加は毎年 $11.5 \%$ で，その中でも 特に目覚ましいものである。そして今後少なくとも10年 間は，その高い生長率は依持されるものと予想されてい る。化学工業のこのような高い成長率はいずれに起无す
るのであろうか？ いろいろの理由があけられようが, 他種製造工業にくらへて化学工業が技術的にも，経済的 にも独特の性格を持ち, 就中研究という強力なバックポ ーンに支えられ推進されているからである。製品ならび にプロセスの急速な陳䧹化というきびしい現実にたえず 务される，競争の激しい化学工業企業間では，研究 (Research) こそがその成長の唯一の要素であり刺激 であり，推進力となっている。著者は第 8 章“化学工業 における企業競争”で，高度の化学工業会社の企業競争 の実体を説明し，さらに第11章で，化学工業の発展と安 定を裹付る重要な要素として, 新しい着想の選択, 研究 の推進，工業化着手，市場開拓，販売政策の検討をあ. け，これが上記化学工業発展の原動力となっているとと を示している。この中で，新着想を評価するための質問 12力条, Olin Industries-が採用している研究価值の標: 準ならびに新製品の工業化について考虑すべき項目とい ろものは，本誌の読者にとっても，確に参考となろう し，興味深いものと思われる。化学工業は他産業と同様 政府の政策ならびそ法令の影響を受けるととが大きく， また国際情勢，殊にその貿易の動向に做感飞支配を受け やすいものであるが (第13,14章)，本書は広い視野に立 って, 一般経済の発展の見透しを基碟に入れつっ，化学: (以下 141 ページへ続く)。 